\title{
STUDY ON INTERNET OF THINGS ELECTRIC SYSTEM BASED ON DISTRIBUTED SMART TERMINALS IN DEMAND SIDE MANAGEMENT
}

\author{
G.L.Zheng ${ }^{1}$, L.Zhang ${ }^{1}$, J.W.Chi ${ }^{2}$ \\ ${ }^{1}$ - Department of Automation, Wuhan University, \\ No. 8, Donghu South Road, 430072, Wuhan, China, E-mail*: zhangli00121@163.com \\ ${ }^{2}$ - Infrastructure Management Department, Wuhan University, \\ No. 299, Bayi Road, 430072, Wuhan, China \\ Demand side management (DSM) plays an important role in enhancing electric power grid operation, which is \\ sophisticated due to the versatility of different loads, the vast number of users as well as the distribution in space and time. \\ Internet of things (IoT), goes without say, is a perfect solution to the bemused situation. In this paper, the construction and \\ implementation scheme of an IoT electricity management system for DSM based on advanced electric smart control \\ terminals and remote load controller (SRLC), is introduced. The system not only achieves real-time online monitoring but \\ also achieves remote dynamic load management integrated with various functions, especially "load feature identification" \\ and "dangerous load shedding" are applied successfully in student dormitories (5 buildings with 750 units) of Wuhan \\ University. A transparent electricity management platform is created on both Wuhan University's information WEB \\ stations (called "cloud") and all the relative students' mobile phones (called "terminal") by this IoT system. The \\ equipment costs are discussed for installing this system. The application results show that the system provides an optimal \\ decision and reliable reference data for building energy management, with additional advantages on safety, low cost and \\ easy implementation with smart power grid or e-Energy. References 15, figures 10.
}

Key words: Smart terminal, Internet of Thing (IoT), Demand Side Management (DSM), electric system.

Introduction. Demand side management (DSM) system are becoming more and more important in the past decade due to a great increase in demand of electric world wide and the appeal of energy saving. Electricity is a special kind of energy product that is instantly consumed as soon as it is produced, therefore, the whole process needs to match demand with available supply in real time. Comparing power generation, power transmission, power supply and power distribution in smart grid, DSM is relatively under-developed in the power industry supply chain $[4,5]$. It is well known that internet brings about new applications to reinvent everyday affair everything we already knew including power system. IoT is a perfect solution to realize demand side management by distributing the vast number of smart electric terminals via "cloud" center of electric management system [3]. In DSM, the keys of IoT system are the smart technologies including intelligent measurement metering infrastructure (AMI) and remote control electric switches. A lot of studies have been achieved [8,10], where a series of traditional remote control wireless power outlet sockets or other devices are used as terminals of power management systems, but that does not imply a big data system that could be achieved with those systems. In reference [14], a design of an intelligent energy management apparatus based on a complicated MCU (Micro Control Unit) is introduced. The equipment can control power simply by switching on/off and record the data of electricity usage, but it is difficult to enhance the controlling capacity and add more functions owing to the structure of the apparatus which is not flexible to extend. In reference [9], the concept of cyber-physics is fused in home device power management. Utilizers manage electricity loads by means of a multi-agent system involving evaluation, monitoring, and control of energy resources. This design may be considered effective, but this is just a general basic prototype. Moreover, a theoretical study is illustrated in [1,15], where a smart home energy system is composed of many dispersive parts including smart meter, smart socket/switch, grid friendly appliance controller, smart interactive terminal and other smart devices, however, it is difficult to apply under acceptable cost-effectiveness for mass applications or large numbers of users.

This paper focuses on a perfect DSM solution for the densely populated dormitories in campus, where thousands of students live and have a complicated power supply scheduling. This means that an IoT electric system need to be designed, which not only can manage and control thousands of electric sockets connected to a variety of electric load but also can prevent the building away from fire due to electric overload and unsafe load through the functions of "load feature identification" and "dangerous load shedding". Meanwhile, this system need to be designed to prevent each dormitory's power load from exceeding the default load limit. Besides, in this IoT system, each piece of electric power consumption information and every power terminal status at various levels are gathered, integrated and analyzed at the "cloud" center, meanwhile the system also

(c) Zheng G.L., Zhang L., Chi J.W., 2016 
manages and controls each of the terminals with embedded energy saving program and intelligence regulations on time.

As is well known that low voltage electric switch is the most popular terminal device, and the most widely used for control and management of electricity equipment. However, the traditional electric switch may generate high-frequency inrush current because the voltage is directly added onto the load which influences negatively on the grid. Consequently when it is cut off, the contactor could generate an electric arc which may also cause shock and instability. In addition, the electric arc will generate huge current and heat which damages the contactor either to be out of shape or carbonized and hence the safe service life of the switches are reduced [7]. The increasing contactor resistance in the switch increases potential risks of being able to catching a fire. Therefore, a new kind of smart terminal which has characteristic with features of remote sensing, remote measuring, remote control, real-time monitoring and dynamic management needs to be developed for IoT electric system in DSM. Even more, the terminal device should be more than a switch and an electricity device with high sensitivity and reliable protection ability, as this is the definition of smart remote load controller (SRLC) [12]. As an important terminal component of the smart grid, the smart load controller will help in achieving the interaction of electricity consumers and power systems.

The purpose of this paper is to research the construction and implementation scheme of an IoT electrical management system based on advanced electric smart control terminals and remote load controller (SRLC) in DSM, and to analyze and compare characteristics of electric power consumption by actual running data form IoT electricity management system.

1. System structure and function. 1.1 The "control terminal" side. Smart remote load controller (SRLC) is selected as the core control terminal device and is used for constructing the distributed electrical system in this paper. This is a typical MPU embedded smart terminal device which is designed based on the patent technology of the AC zero-crossing [6] and has an electric power input interface and remote multi controllable electric output. The main related products include three-phase smart remote load controller (STSRC), three-phase smart motor controller (ST-SMC), single-phase four-channel smart remote load controller (ST-SRLC-4) and single-phase ten-channel smart remote controller (ST-SRLC-10). These products are also known as "ST series products". The characteristics of ST series products which have integrated TCP/IP protocol

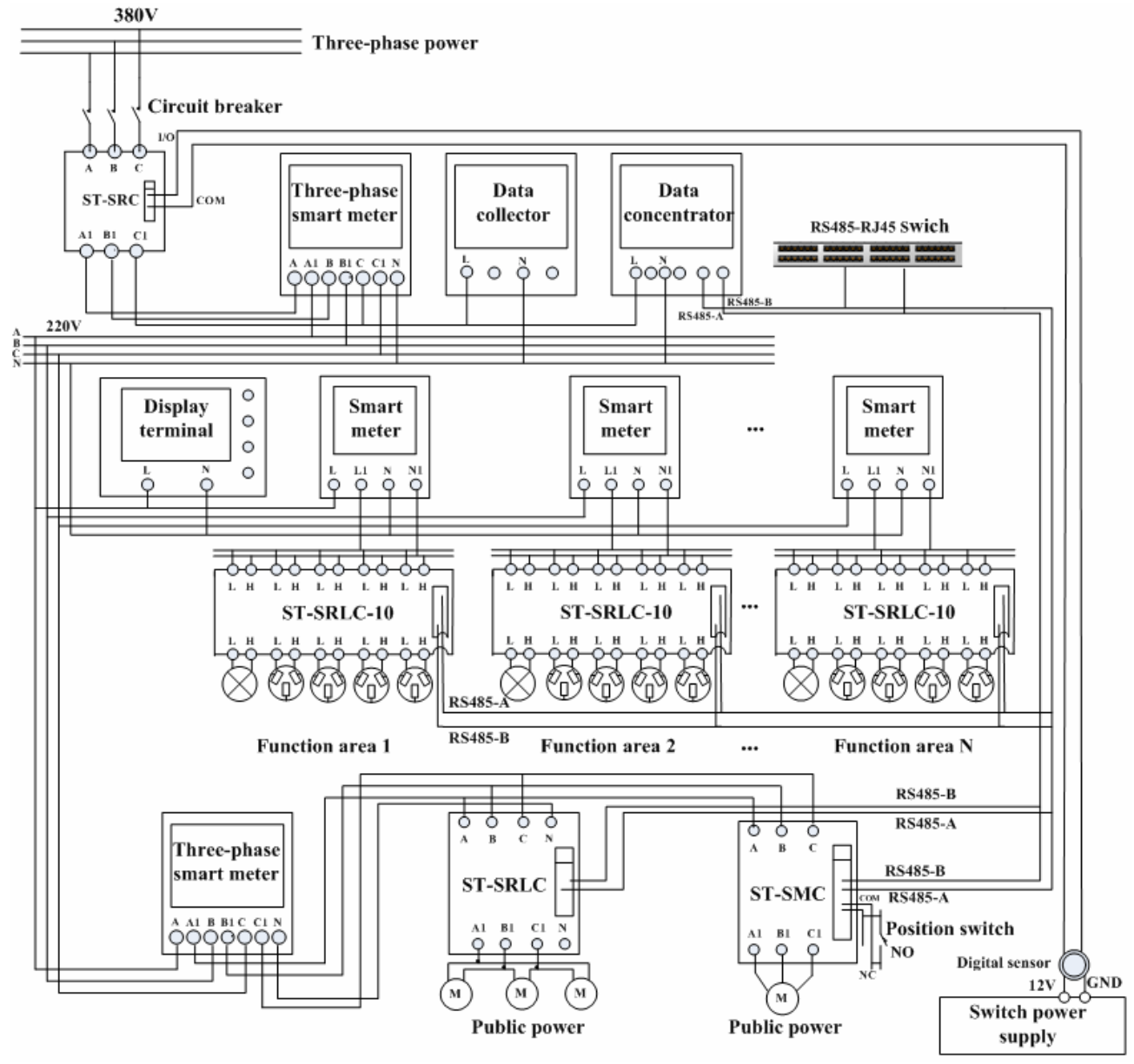
are no arc, long life, low power consumption and economic. They support, such multicommunication modes as RS485, CAN, Zigbee, WiFi etc., and can complete a circuit protection action within $20 \mathrm{~ms}$ so that electrical accidents and fire hazards are prevented preemptively.

Fig. 1 shows the schematic diagram of distributed electrical structure in control terminal side, according to the functional requirements of control area in buildings. Distributed wiring optimization method is adopted for electrical structure where power supply to all different electric loads. Each smart load controller

Fig. 1 
can be used as a separate control unit for wiring to achieve distributed control and management. The characteristics of both ST-SRLC-4 (rated power of each channel :20 kW ) and ST-SRLC-10 (rated power of each channel :2 kW ) at single phase stage are $220 \mathrm{~V} \mathrm{AC}, 50 \mathrm{~Hz}$, as well as at city power supply stage are 400 $\mathrm{V} \mathrm{AC}, 50 \mathrm{~Hz}, 50 \mathrm{~kW}$. Each of the load from the $380 \mathrm{~V} \mathrm{AC}$ stage to distributed end loads are all under monitoring and control of the smart meters and smart controllers that forms the terminal side including lights, sockets, motors, pumps, etc. for IoT electric system in DSM.

1.2 The "cloud" side. Fig. 2 shows the overall function structure of the system in the "cloud" side. The "cloud" management side includes computer server, smartphones, self-service terminals, intelligent interactive App on mobile terminals and so on. According to different function aim, the "cloud" side construction of intelligent electricity management system consists of the basic electricity management platform (BEMP) and bidirectional interactive platform (BIP). Both are designed in information intranet and extranet respectively, and information security protection is ensured by special physical isolation device of

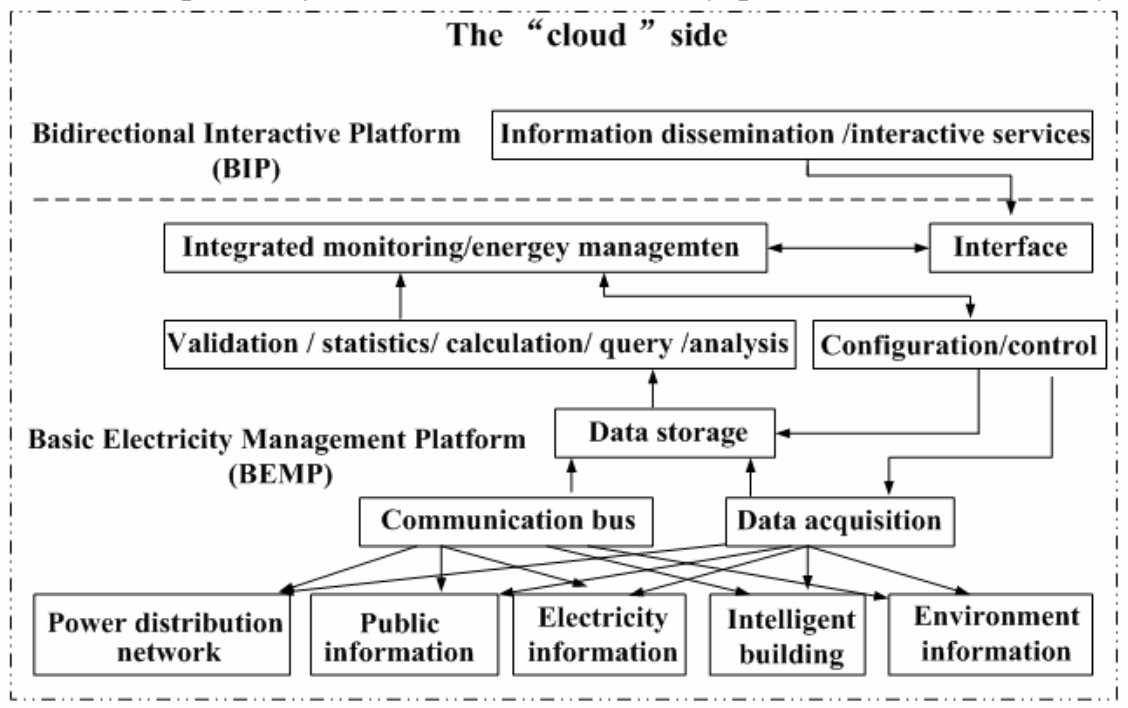

Fig. 2 power system. The client/server $(\mathrm{C} / \mathrm{S})$ architecture is used for achieving the data access, power distribution monitoring, energy management and analysis of energy efficiency data and so on in BEMP. The browser/server $(\mathrm{B} / \mathrm{S})$ architecture is adopted in BIP to complete information dissemination and interactive services. In order to meet the heterogeneous demand of IoT, the network architecture which is open, layered and has extendibility needs to be constructed on the "cloud" side $[2,11]$

On the "cloud" management side, without any boundary in terms of time and location, all of the relevant users and managers can monitor and control their own electric appliance and understand their energy consumption process, their relevant electric loads in real time, status and history of their power consumption as well as the power supply quality. Meanwhile, the electric management center can still carry on the remote control and intelligent management of electricity load in student dorm. The whole process of electric power consumption is transparent and the following key issues are solved by this IoT system. 1. Data acquisition. It supports online dynamic monitoring of electrical parameters, such as voltage, current, power, power factor and so on, as well as identifying the different types of real time loads in order to make intelligent decisions to optimize electrical power supply and consumption. 2. Data processing. It enables fast and intelligent load protection by analyzing and processing the collected data, such as the situation of overvoltage, under-voltage, over-current and shortage of the three phases. 3. Electricity control. It includes remote sensing, measuring and load control via smart remote load controller (SRLC). 4. Communication network. It has communication capability by combining the all kinds of networks that possibly present among distributed smart load controllers, meters and the "cloud" management center. 5. Load analysis and identification. This achieves accurate analysis and load features identification in real time [13], enhances intelligent energy saving and power coordination via use of accurate forecast model, and provide scientific optimal decision-making for power management departments.

1.3 The overall architecture of system. The intelligent electricity management technology is one of the key technologies in terminal control of smart grid, which is also the foundation of information acquisition and networking in DSM. Fig. 3 shows a typical control topology structure of intelligent electricity management system, which is designed for creating the flexible and interactive WEB platform. The main tasks includes four aspects: $\mathbf{1}$ - Applications to all kinds of buildings; $\mathbf{2}$ - Series of electric distributed wire based on SRLC and smart meters; 3 - The mobile App software for user side; $\mathbf{4}$ - The "cloud" side management software and data base program. 
In Fig. 3, the hardware framework of the system mainly consists of four layers including cloud service, communication channel, terminal devices and application objects. The first layer includes servers, workstations, master computer, smart-phone, PAD and mobile terminal etc.

The function is to complete data collection and analysis, data storage, and remote control by upper computer. The second layer is composed of gateway, route and communication module and so on. It is a transmission link between upper computer and lower computer for instruction communication and data transceiver. The third layer includes smart load controller, smart meter, data collector and the various digital sensors etc. Smart remote load controller (SRLC) is a key terminal unit in the system design. It can complete data acquisition, data processing and information communication of on-site power load by combining with the smart meter, data collector, data concentrator, communication server and computer master server, etc., and maintaining the control and management of the electricity load in buildings. The last layer is services subject in DSM, including residential buildings, office buildings, shopping malls, hotels and other application objects.

To sum up, the construction and

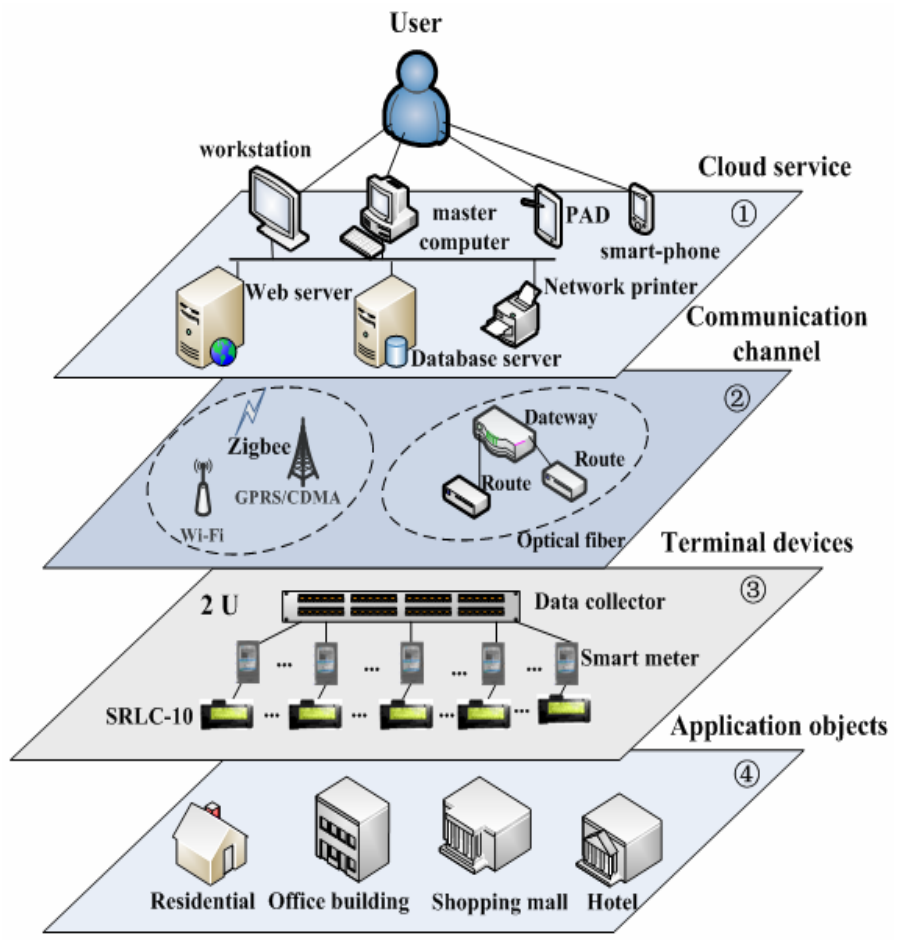

Fig. 3 implementation of an intelligent IoT electricity management system is proposed, it has following five critical characteristics that are : 1 - Only electric power cable need to be used -no need for communication wires; 2 Sufficient capability to support the power load as demanded; $\mathbf{3}$ - All information including electricity parameters and load status is within a network and could be transferred to the "cloud" data side; $\mathbf{4}$ - Every smart terminal is under the dual control of authorized orders from the "cloud" center and the authorized user in question; $\mathbf{5}$ - The system should be easily expanded to any scale (any number of buildings on the campus), from a single campus to a city or even a country. Moreover, the system has successfully achieved its designed performance parameters in Wuhan University since its COD on Sep.1, 2014. The electricity trends can be found through analysis and processing of historical data in intelligent management platform. The application shows that this system provides optimized decision-making method of electricity utilization for campus management department, and is able to support with more reliable reference basis and scientific data for building reconstruction or line rectification in future.

2. Data analysis and comparison of electric power consumption. The analyzed sample data come from the built intelligent electricity management system that is assembled on the "cloud" server in Information Center, Wuhan University. As the first step of the project of Wuhan University's IoT electric system, it include five campus buildings with 750 units. Among them, there are three buildings in the Information Engineering District, named IED NO.2, IED NO.5, and IED NO.6, where IED NO.2 and IED NO.6 are for female undergraduate students, IED NO.5 is for female graduate students. In addition, two buildings are undergraduate apartments in Medical Science District, namely MSD NO.1 and MSD NO.2, where MSD NO.1 is a female dormitory and MSD NO.2 is a male dormitory. Each dormitory contains four person, the fixed electrical equipment includes an air conditioner (Peak-power: $1.5 \mathrm{~kW}$ ), 4 lamps (Total power: $120 \mathrm{~W}$ ) and 8 electric sockets used other uncertain electrical equipment. Air conditioning electric power consumption and lighting \& sockets electric power consumption are separately measured and recorded by smart meter. There are subsidies for lighting $\&$ sockets electricity $(8 \mathrm{~kW} \cdot \mathrm{h}$ is free for each student in each month) in university from government, however, air conditioning electricity is not free of charge, and is selfpaying charge. The data under study for this paper are collected via the IoT DSM system from all 5 buildings in the time domain from Sep.1, 2014 to Jan.31, 2015. 
2.1 The total electric power consumption. The IoT DSM system of 5 student dormitory buildings on campus of Wuhan University, which acts as an electricity "big data" system and collects a large amount of parameters from a total of 750 dormitory units, such as voltage, current, load power, load power factor,

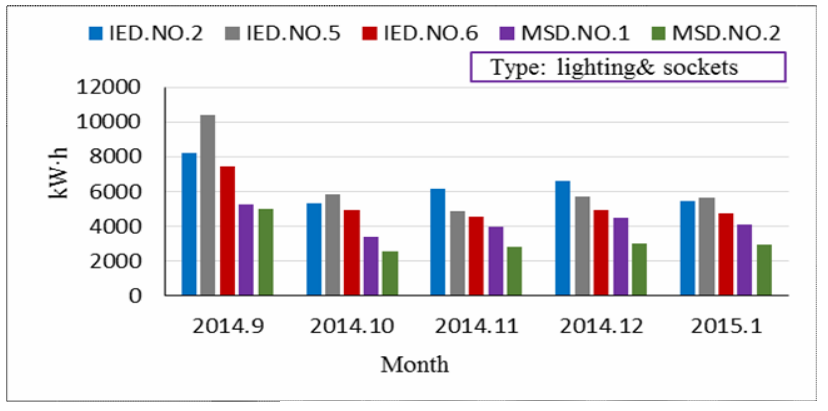

$\boldsymbol{a}$

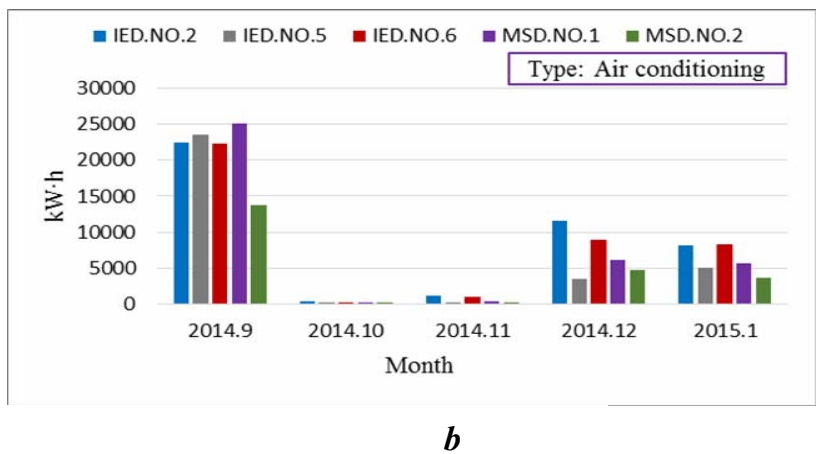

Fig. 4

electric power consumption, switch state, payment records, deduction records and so on. The electric power consumption can be analyzed by comparing the different buildings, different student groups as well as different time periods. Fig. 4 shows the total electric power consumption status of lighting \& sockets and air conditioning respectively, for the five buildings in five different months after such system has been installed in university campus.

The results of analysis of data Fig. 4 are as follows:

1. In September, the total electric power consumption (from room lamps, sockets and room airconditioning) are all significantly higher than any other months in five dormitory buildings. The reason is that the university provides free electricity policy for ventilation and odor removal when new buildings are put into use for freshman in the first month. At the same time, the average temperature had been above $28{ }^{\circ} \mathrm{C}$ during the days in Sept., 2014, Wuhan, China. That results in full operation in almost all the air conditioners and fans.

2. The system starts charging on Oct.1, 2014, which results in a stable increment of the total monthly electric power consumption of the five buildings without big fluctuations. Overall, the whole electric power consumption of Information Engineering District (IED) is higher than Medical Science District (MSD) due to the difference in course study and time schedule.

3. In 2014, both October and November are in the autumn, the temperature is moderate in Wuhan, where the use of air-conditioning is comparatively less than in Sept., hence the recorded electric power consumption is also less. However, air-conditioning electric power consumption increased gradually as the weather is getting cold in December.
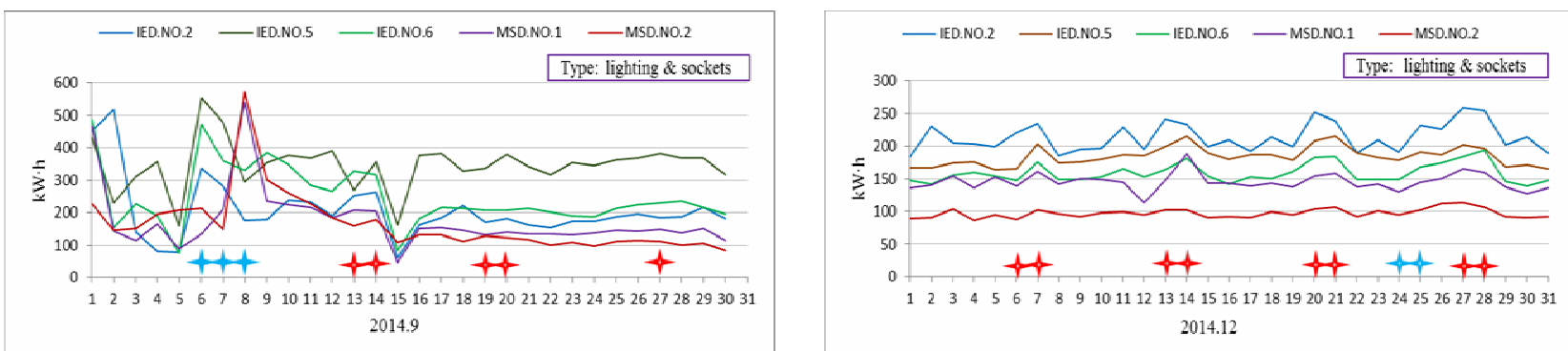

Fig. 5, $a, b$
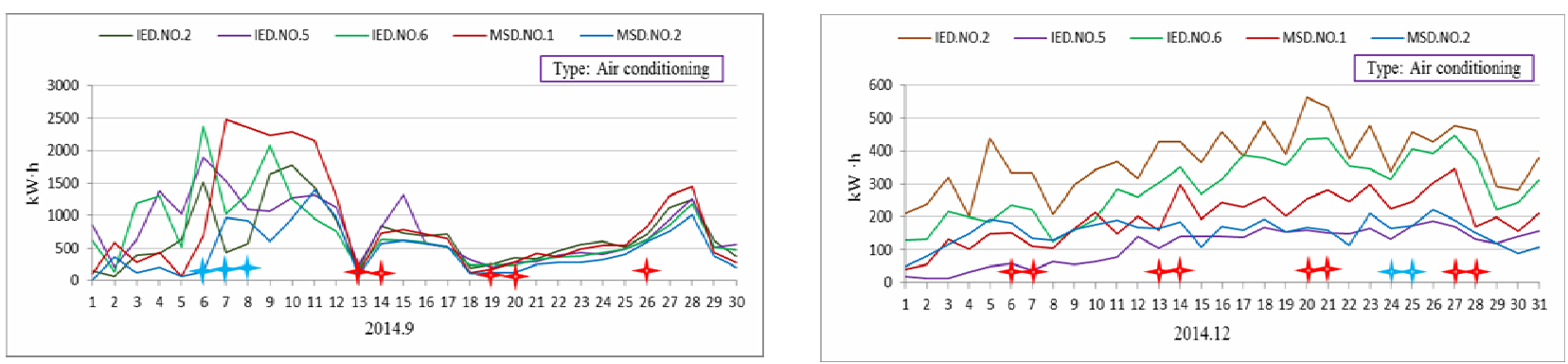

Fig. 6, $a, b$ 
Price of electric power consumption from dormitories are significant different because the air conditioners causes bigger electric power load.

2.2 The trend of monthly electric power consumption. There are two types of electric power consumption in campus: the lighting \& sockets electricity and air-conditioning electricity in each dormitory. 8 $\mathrm{kW} \cdot \mathrm{h}$ is free for each student in each month for lighting \& sockets electricity, however, air conditioning electricity is not free of charge. The compared objects in this paper are discussed in three charts below: $\mathbf{1}-$ An electric power consumption as compared different buildings in the same month are shown in Fig. 5 and Fig. 6; 2 - An electric power consumption for Master student and undergraduate student of the same district in different months are shown in Fig. 7 and Fig. 8; 3 - Electric power consumption for male students and female students of the same district in different months are shown in Fig. 9 and Fig. 10.

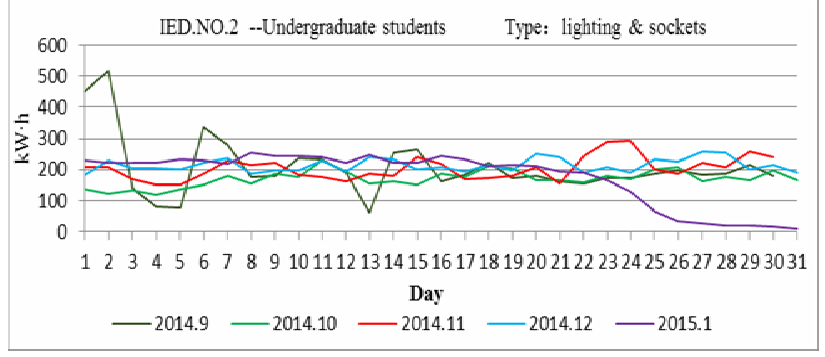

$a$

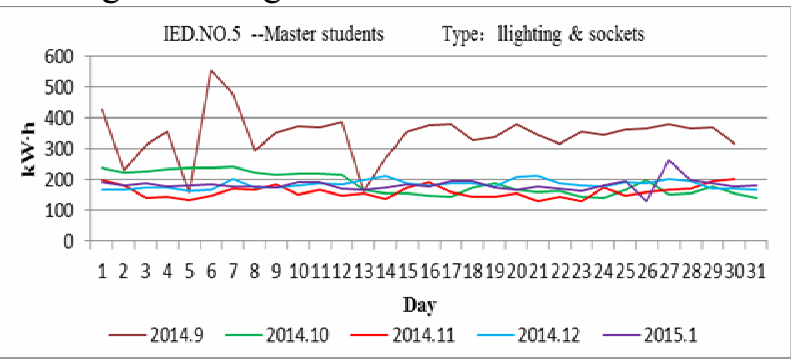

$b$

Fig. 7

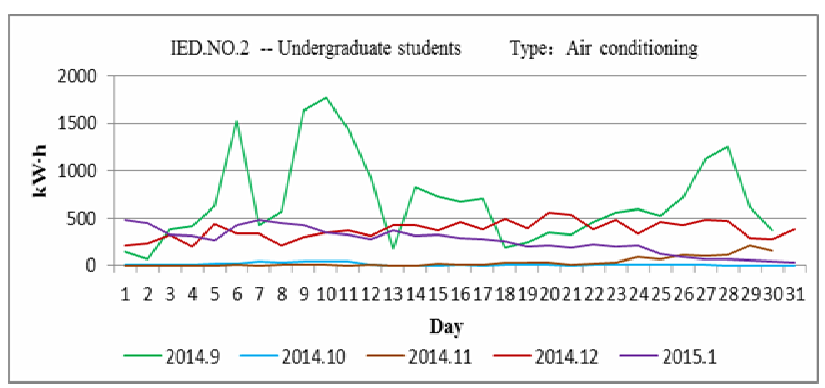

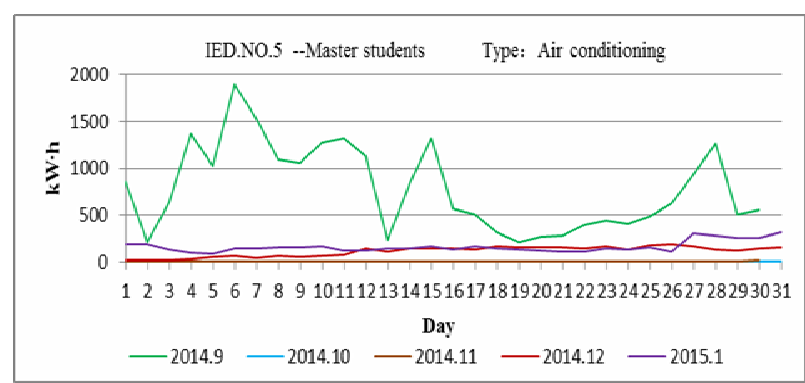

$b$

Fig. 8

Fig. 5 shows lighting \& sockets electric power consumption of different buildings in Sep.2014 and in Dec.2014. Fig. 6 shows air-conditioning electric power consumption of different buildings in Sep.2014 and in Dec.2014. In Fig. 5 and Fig. 6, "red star" represents weekends and "blue star" represents holidays or special holidays. As shown in the graph, is air-conditioning or light electricity, the monthly electric power consumption has a rising trend on weekends or holidays. However, the daily electric power consumptions fluctuate greatly due to free electricity policy (In Wuhan University, electricity fee is free for freshman in the first month) in September. After a period of free electricity, the growth of air-conditioning electric power consumption is relatively stable for the example in Dec., 2014.

In this paper, IED.NO.2 (Undergraduate students) and IED.NO.5 (Master graduate students) are chooses to compare with each other. Fig. 7 shows lighting \& sockets electric power consumption for Master students and Undergraduate students. Fig. 8 shows air-conditioning electric power consumption comparisons between Master students and Undergraduate students. In Fig.7, the daily light electricity consumption increases smoothly during the whole period with little volatility. The electric power consumptions of undergraduate students compared to the Master students are slightly higher. The reason for this is that the undergraduate students tend to stay in their dorm story twice as much time as compared to that of graduate students, who typically spend more time in labs. Also Fig. 8, gives that for Master Students or undergraduate students the air-conditioning electric power consumptions, are the highest in September and have many fluctuations owing to free electricity policy. When the weather went colder, the air-conditioners were more frequently put into use for heating, therefore the electric power consumptions increased gradually. The electric 
power consumptions of undergraduate students is higher than for Master students. It means that the higher grade students knew more about how to use electricity properly and how to adapt to seasonal change.
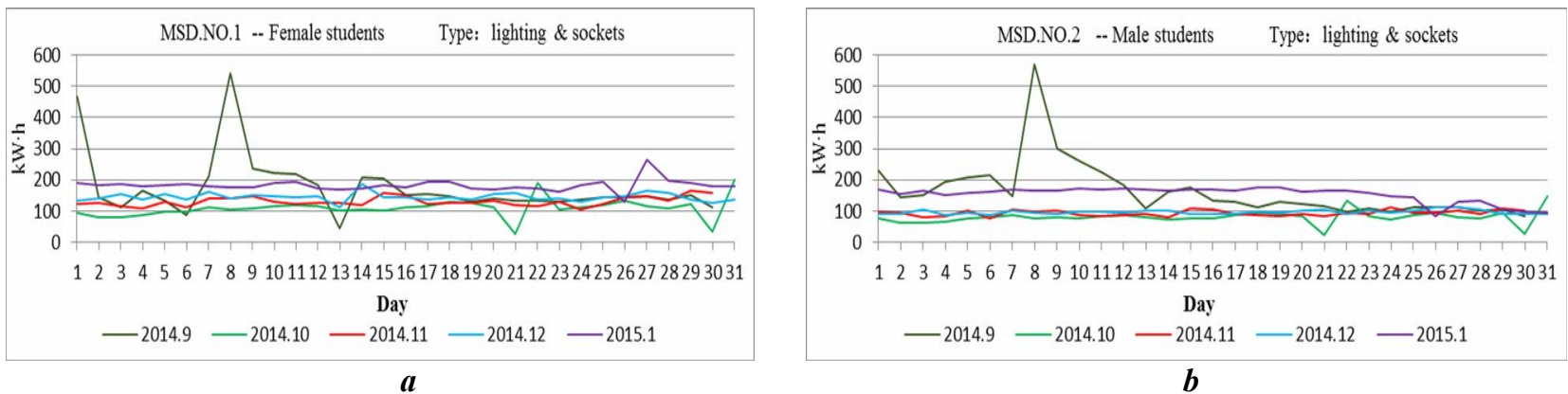

Fig. 9
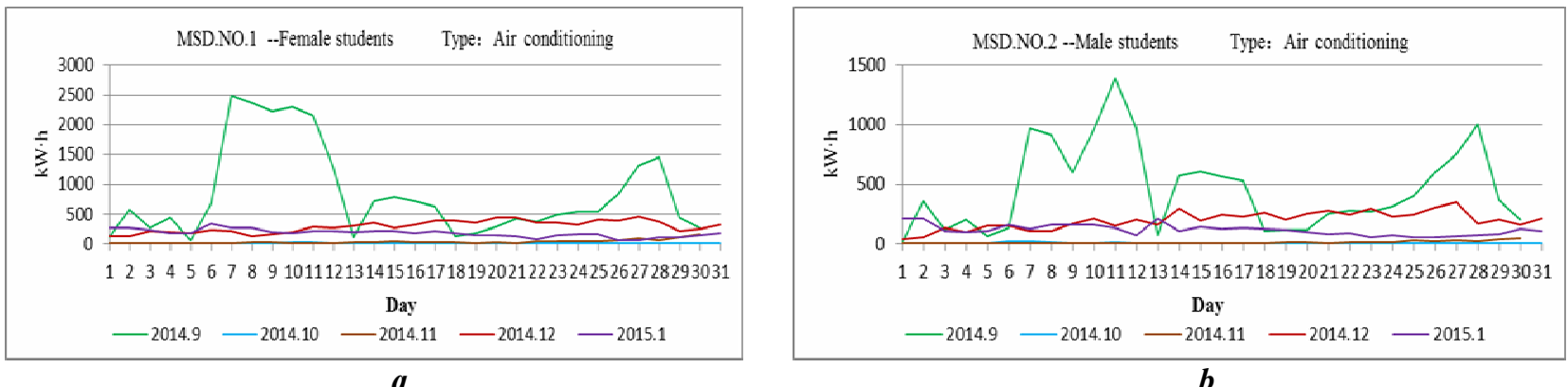

Fig. 10

MSD NO.1 (Female students) and MSD NO.2 (Male students) are chosen as variables for comparison. Fig. 9 shows lighting \& sockets electric power consumption for male students and female students. Fig. 10 shows air-conditioning electric power consumption for male students and female students. In Fig.9, the lighting electricity daily consumption increases smoothly during the entire period of the graph with little volatility. By calculating the average lighting electric power consumption of five months, the results show that the electric power consumptions of female students were more than that of male students. This could imply that types of electrical equipment connected to electric sockets in female dormitory are more than that in male dormitory. In fact, that is true, the girls prefer to use some type of electrical appliances than boys by questionnaire survey, such as hair dryer, egg cooker, hand warmer and so on. Fig. 10, the air-conditioning electric power consumptions for both MSD NO.1 (Female students) and MSD NO.2 (Male students) are at their highest and had much fluctuations because of the free electricity policy in September. When the weather went colder, the air-conditioning electric power consumptions are increased gradually since Dec.2014, but the average air-conditioning electric power consumption of female students is slightly higher than that of male students, the reason is that the girls one less capable to stand the cold weather and spend more time staying in the dormitory in winter.

3. Equipment cost. For example, the costs of equipment for new dormitory buildings having six floors and 25 rooms in each floor are listed in table below. As assumed, each room is equipped with two smart meters for metering of the air conditioning and lighting \& sockets electric power consumption. The RMB to USD conversion rate $(1 \mathrm{RMB}=0.154 \$)$ in 2015 is used in the table.

Data in the table give the following total cost for each subsystem.

1. Cloud service subsystem for medium scale $-\$ 4,585$.

2. Communication subsystem for medium scale $-\$ 10,215$.

3. Terminal control subsystem for all devices $-\$ 30,667.56$.

4. Service and application entrance $-\$ 9,700$.

The total estimated cost of equipment for new dormitory buildings is equal to $\$ 55,167.56$. The cost for each room is approximate 368 dollars. 


\begin{tabular}{|c|c|c|c|}
\hline \multirow{2}{*}{ Subsystem } & \multirow{2}{*}{ Notes } & \multicolumn{2}{|c|}{ Price per unit } \\
\hline & & Average & Range \\
\hline \multirow{3}{*}{ Cloud service } & Small (Points: < 25) & $\$ 1,850$ & $\$ 1,050-2,625$ \\
\hline & Medium (Points: $>25,<100$ ) & $\$ 4,585$ & $\$ 3,150-10,500$ \\
\hline & Large (Points: $>100)$ & $\$ 6,825$ & $\$ 5,250-21,000$ \\
\hline \multirow{3}{*}{ Communication } & Small (Points: $<55$ ) & $\$ 6,585$ & $\$ 4,650-8,525$ \\
\hline & Medium (Points: $>55,<350$ ) & $\$ 10,215$ & $\$ 13,950-54,250$ \\
\hline & Large (Points: $>350$ ) & $\$ 52,500$ & $\$ 23,250-77,500$ \\
\hline $\begin{array}{c}\text { Service and } \\
\text { application entrance }\end{array}$ & 2 & $\$ 4,850$ & $\$ 4,850-8,550$ \\
\hline \multirow{8}{*}{ Terminal control } & Number & $\begin{array}{l}\text { Price per } \\
\text { terminal }\end{array}$ & Total \\
\hline & ST-SRLC-10 ( Num.: 36 ) & $\$ 277.20$ & $\$ 9,979.20$ \\
\hline & ST-SRC( Num.: 6 ) & $\$ 207.90$ & $\$ 1,247.40$ \\
\hline & ST- SMC ( Num.:6) & $\$ 231.00$ & $\$ 1,386.00$ \\
\hline & ST-SRLC-4 ( Num.: 6 ) & $\$ 200.20$ & $\$ 1,201.20$ \\
\hline & Single-phase smart meters( Num.: 306 ) & $\$ 36.96$ & $\$ 11,309.76$ \\
\hline & Three-phase smart meters( Num.: 12) & $\$ 277.20$ & $\$ 3,326.40$ \\
\hline & Smart display terminal (Num.: 6) & $\$ 369.60$ & $\$ 2,217.60$ \\
\hline
\end{tabular}

Conclusion. In this paper, the implementation scheme of an electric IoT system for DSM is discussed. The constructed IoT system is covered 5 dormitory buildings in Wuhan University. This system was designed based of smart remote load controller (SRLC) and smart meters which achieved real-time online monitoring, control and remote management of dynamic load. At the same time, the system allows managers and students to control electricity usage via smartphones, IPad or other kinds of terminals through campus Intranet or WLAN of Wuhan University. A student is authorized to monitor the information of electric system in his/her dormitory, as well as the administrators of the building can monitor and control all the power loads in the buildings under his/her responsibility. This system was a breakthrough managing power supply, gives students play a self-managing role in monitoring their electric power consumption and pay electricity fee via their smart phones. By analyzing collected data of the system, the electricity usage of students are summarized to provide scientific data and reference for constructing the similar electric IoT system in campus buildings. The application and scaling of the technology could provide not only a more convenient, transparent and remote controllable electricity system but also effectively improve energy efficiency and energy management via demand response. The application of the IoT system reduces $98 \%$ of building management workload, meanwhile it guarantees the electrical supply safety and enhances intelligent management of buildings.

This work was supported in part by National Natural Science Foundation of China under Grant No. 61272114, Marine Renewable Energy Special Fund Project of the State Oceanic Administration of China under Grant No.GHME2013JS01. Corresponding author is Li Zhang (IEEE Member, Doctor), who specializes in smart grid and detecting technology.

1. Anvari-Moghaddam A, Monsef H, Rahimi-Kian A. Optimal Smart Home Energy Management Considering Energy Saving and a Comfortable Lifestyle // IEEE Transactions on Smart Grid. - 2015. - Vol. 6. - No 1. - Pp. 324-332.

2. Avramenko V., Martyniuk A., Hurieieva $T$. Study of amplitude-frequency spectra of active power through power system transmission lines // Tekhnichna Elektrodynamika. - 2015. - No 3. - Pp. 47-51. (Ukr)

3. Barbato A., Capone A., Chen L., et al. A Distributed Demand-Side Management Framework for the Smart Grid // Computer Communications. - 2015. - Vol. 57. - No C. - Pp. 13-24.

4. Behrangrad $M$. A review of demand side management business models in the electricity market// Renewable \& Sustainable Energy Reviews. - 2015. - Vol. 47. - Pp. 270-283.

5. Colak I., Kabalci E., Fulli G., et al. A survey on the contributions of power electronics to smart grid systems // Renewable \& Sustainable Energy Reviews. - 2015. - Vol. 47. - Pp. 562-579.

6. Guilin Zheng. Three-phase smart controller // Invention patent. - NO.ZL2010 10184066.2 . 2011. (Chn)

7. Jiaoming Liu. The Study on Movement Mechanism and Simulation of Low Voltage Switching Arc. Science Press: Binjing, 2013. - 185 p.

8. Keles C., Karabiber A., Akcin M., et al. A smart building power management concept: Smart socket applications with DC distribution // International Journal of Electrical Power \& Energy Systems. - 2015. - Vol. 64. - Pp. 679-688. 
9. Maasoumy M., Nuzzo P., Sangiovanni-Vincentelli A. Smart Buildings in the Smart Grid: Contract-Based Design of an Integrated Energy Management System, Cyber Physical Systems Approach to Smart Electric Power Grid. - Springer: Berlin, 2015. - 132 p.

10. R., Joumaa H, Ploix S., et al. Managing energy Smart Homes according to energy prices: Analysis of a Building Energy Management System // Energy \& Buildings. - 2014. - Vol. 71. - Pp. 155-167.

11. Sheikhi A., Rayati M., Bahrami S. A cloud computing framework on demand side management game in smart energy hubs // International Journal of Electrical Power \& Energy Systems. - 2015. - Vol. 64. - Pp. $1007-1016$.

12. Suntrans. Available at: http://suntrans.net/Web/Chinese/ProductInfo/ProductsDetail.aspx? Product ID=46. - 2014. (Chn)

13. Wang Z., Zheng G. Residential appliances identification and monitoring by a nonintrusive method // Smart Grid, IEEE Transactions on. - 2012. - Vol. 3. - No 1. - Pp. 80-92.

14. Zhihong X.U. Technology Solutions of Control Electric Apparatus Service in Energy Management System // Low Voltage Apparatus. - 2013. - No 1. - Pp. 14-19.

15. Zhou H., Lai J., Hu W., et al. Demand-side energy management: FTTH-based mode for smart homes // in American Control Conference (ACC), IEEE, Portland, USA. - 2015. - Pp. 1704-1709.

\section{УДК 621.317 \\ ИССЛЕДОВАНИЕ СИСТЕМЫ «ИНТЕРНЕТ ВЕЩЕЙ» НА ОСНОВЕ РАСПРЕДЕЛЕННЫХ ИНТЕЛЛЕКТУАЛЬНЫХ ТЕРМИНАЛОВ УПРАВЛЕНИЯ СПРОСОМ В ЭНЕРГОСИСТЕМЕ G.L.Zheng ${ }^{1}$, L.Zhang ${ }^{1}$, J.W.Chi ${ }^{2}$ \\ 1 - Department of Automation, Wuhan University, \\ No. 8, Donghu South Road, 430072, Wuhan, China, E-mail*: zhangli00121@163.com}

2 - Infrastructure Management Department, Wuhan University, No. 299, Bayi Road, 430072, Wuhan, China.

Управление спросом играет важную роль в улучшении работы электроэнергетических сетей, которые отличаются сложностью из-за наличия различных нагрузок, большого числа потребителей, распределения в пространстве и времени. Кониеепия «Интернет вещей» является идеальным решением для такого случая. В статье представлена схема построения и реализации этой конщепции для систем управления спросом электроэнергии, основанной на современных управляющих смарт-терминалах и устройствах дистанционного регулирования нагрузок. Система обеспечивает мониторинг в режиме реального времени, дистанционное управление нагрузкой в соединении с различными функииями, и, в частности, функииями определения параметров нагрузки и аварийного сбрасывания нагрузки. Система успешно применяется в студенческих общежситиях (5 зданий с 750 блоками) Уханьского университета в Китае. Посредством системы «Интернет вещей» создана прозрачная платформа управления электроэнергией, которая включает информационные веб-станции Уханьского университета (называются «облаком») и мобильные телефоны всех студентов (называются "терминалами").

Применение системы показало, что она представляет собой оптимальное решение, дает надежную базу данных для управления энергопотреблением и обладает преимуществами: безопасностью, низкой стоимостью, простотой внедрения 8 смарт-энергосети или е-Energy. Библ. 15, рис. 10.

Ключевые слова: смарт-терминал, Интернет вещей, управление спросом, электрическая система.

УДК 621.317

ДОСЛІДЖЕННЯ СИСТЕМИ «ІНТЕРНЕТ РЕЧЕЙ» НА ОСНОВІ РОЗПОДІЛЕНИХ ІНТЕЛЕКТУАЛЬНИХ ТЕРМІНАЛІВ ДЛЯ УПРАВЛІННЯ ПОПИТОМ ЕНЕРГОСИСТЕМІ G.L.Zheng ${ }^{1}$, L.Zhang ${ }^{1}$, J.W.Chi ${ }^{2}$

1 - Department of Automation, Wuhan University, No. 8, Donghu South Road, 430072, Wuhan, China, E-mail*: zhangli00121@163.com

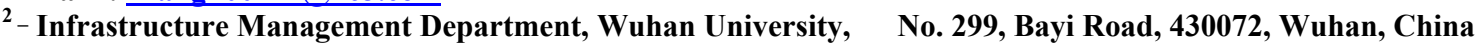

Управління попитом відіграє важливу роль у підвищенні роботи електроенергетичної мережі, яка є складною через багатогранність різноманітних навантажень, значної кількості користувачів та розподіл у просторі і часі. Зрозуміло, щьо система типу «інтернет речей» є ідеальним ріменням у даній ситуачії. У статті представлено схему побудови та реалізачіі иієї концепчї для управління попитом електроенергї̈ на основі сучасних смарт-терміналів управління і пристроїв дистанційного регулювання навантаження. Система забезпечує он-лайн моніторинг у режимі реального часу, дистанційне управління навантаженням, об'єднаного з різними функиіями, $i$, зокрема, функиіями визначення параметрів навантаження та аварійного скидання навантаження. Система успішно застосовується у студентських гуртожитках (5 будівель з 750 блоками) Уханьського університету у Китаї. За допомогою системи "інтернет речей" створена прозора платформа управління електроенергією, яка включає інформачійні веб-станції (називаються "хмари") Уханьського університету та мобільні телефони всіх студентів (називаються "термінали").

Застосування системи показало, щзо вона є оптимальним рішенням, дає надійну базу даних для управління енергоспоживанням та має такі переваги: безпека, низька вартість, легке впровадження у смарт-енергомережі та е-Eпегgy.

Бібл. 15, рис. 10.

Ключові слова: смарт-термінал, Інтернет речей, управління попитом, електрична система. 